\title{
On the Design of Interest-Free Instruments ${ }^{(*)}$
}

\author{
Ali F. DARRAT AND M. SHAHID EBRAHIM \\ Premier Bank Endowed Professor of Finance \& Professor of Economics \\ Louisiana Tech University, U.S.A.; and \\ Visiting Assistant Professor of Finance \& Real Estate \\ University of Illinois-Urbana Champaign, U.S.A.
}

\begin{abstract}
The main purpose of this paper is to present a theoretical model of an alternative fund-raising scheme for Muslim governments which are restricted by religious regulations against fixed-interest debt financing techniques. The proposed instrument is developed using the principles of a partial equilibrium theory for risk neutral as well as risk averse investors. The paper concludes with theoretical and empirical discussions on the efficiency of the financial instrument proposed.
\end{abstract}

\section{Introduction}

Since the early 1980s, there has been a phenomenal resurgence of Islamic values in many Muslim countries throughout the world. In the direction of economics, several Muslim countries (e.g., Iran, Pakistan and the Sudan) have recently adopted many practical steps towards "Islarnizing" their economic system. The most notable distinction of such an Islamic economic system is the prohibition of the payment or receipt of a predetermined interest rate which is considered usury ${ }^{(1)}$.

A number of Muslim economists, e.g., M. N. Siddiqi (1991), have argued that the interest-free (profit-sharing) equity participating contracts are more efficient compared to the fixed interest-based arrangements, a theoretical conclusion that Bashir and Darrat (1992) and

(*) The authors would like to thank S. A. Kader and two anonymous reviewers of this Journal for many helpful suggestions. Thanks also go to the participants in the Fifth International Islamic Economics Seminar held at the World Bank, Washington, D.C., October, 1993 to which this paper was presented. The usual disclaimer applies. (1) The Quran is very explicit in prohibiting all interest-based transactions. For example, in Chapter 2, verses 278 279, the Holy Quran states (roughly translated), "0 you who believe! Observe your duty to Allah and give up what remains from Riba (interest), if you are believers. And if you do not, then be warned of war from Allah and His Messenger. And if you repent, then you have your principals (without interest). Wrong not, and you shall not be wronged". See Mirakhor (1988) and Ebrahim (1992) for further discussion. 
Bashir, Darrat and Suliman (1993) have recently corroborated on empirical grounds. Indeed, some prominent western economists like Simon (1948) and Kindleberger (1985) have also proposed certain economic reforms which, if implemented, could transform Western banks to a system resembling that of the Islamic interest-free banks.

While selling equity (with no predetermined fixed interest-rate) can easily be used to finance long-term projects, such a method is clearly infeasible to finance short-term projects due to the ensuing high degree of risk ${ }^{(2)}$. Consequently, short-run financing needs require some sort of debt contracts. Unfortunately, most debt contracts are unsuitable for Muslim countries for they entail usurious fixed interest. As Mirakhor (1988), Dorph (1990) and Zaman (1992) have recently argued, Islamizing contemporary economic systems requires the design of debt instruments that closely conform to the Islamic prohibition of fixed interest rates ${ }^{(3)}$.

Our main purpose in this paper is to do just that, i.e., to design an efficient interest-free security which can be made available to Muslim governments to finance short-term developmental projects. The availability of such financial instruments can also aid central banks in Muslim countries in executing open market operations for the purpose of controlling the supply of money. The proposed instrument emphasizes the optimal sharing arrangement between individual buyers (lenders) and the Government (borrower) who issues the instrument on the basis of variable tax revenues. We model the interest-free instrument in the context of a two-period partial equilibrium theory under the initial assumption of risk neutrality. Once a closed-form solution is obtained, we then extend our analysis to the more realistic case of risk averse.

The remainder of the paper is organized as follows. Section II presents a theoretical underpinning for the proposed interest-free instrument. Section III contrasts the efficiency of the proposed interest-free instrument with that of the interest-based instrument of western economies. Section IV provides some concluding remarks.

\section{Modeling an Interest-Free Financial Instrument}

Consider the following two-period partial equilibrium model. At time $\mathrm{t}=0$, there are $\mathrm{N}$ agents in the economy, who are young in period $t=0$, old/retired in period $t=1$, and dead period $\mathrm{t}=2$ and beyond. All investors have endowments of $\mathrm{w}_{\mathrm{o}}$ in period $\mathrm{t}=0$, and endowments of $\mathrm{w}_{1}$ at the age of retirement. There is only one asset in this economy i.e. a risky loan from the investors to the government. For $\mathrm{t}=0$, the investor may consume his endowment $\mathrm{w}_{0}$ or loan it out. The investor retires in period ${ }^{(1)}$ and consumes endowment $\mathrm{w}_{1}$ and pay-back from the loan. The government realizes a variable tax revenue $\mathrm{T}$ distributed in such a way that it has a minimum $\mathrm{T}_{0}$ and a maximum $\mathrm{T}_{\mathrm{M}}$. The analysis is illustrated below.

(2) As shown by Ebrahim (1993), the standard deviation of equity returns as a measure of risk exhibits a strong negative relationship with the holding period. This is commonly known in the literature as the time-diversification effect of equity.

(3) Some financial observers have privately informed the authors that several forms of interest- free securities (e.g., Income bonds and Tax Anticipation Notes) have actually been used by the governments of Jordan and Malaysia for some rime. See also Khan (1983). 


\section{A. Modeling the Objective Function of Agent/Investor}

The first step is to optimize the expected utility of an investor subject to budget constraints:

$$
\begin{aligned}
& \operatorname{Max}_{0} \quad\left\{\mathrm{U}\left(\mathrm{c}_{0}\right)+\gamma \mathrm{U}\left(\mathrm{c}_{1}\right)\right\} \\
& \text { (in } Q_{0}, \mathrm{c}_{0}, \mathrm{c}_{1} \text { ) }
\end{aligned}
$$

Subject to:

$$
\begin{aligned}
& \mathrm{c}_{0}+Q_{0}=\mathrm{w}_{0} \\
& \mathrm{c}_{1}=\mathrm{w}_{1}+Q_{0} \Theta
\end{aligned}
$$

where:

$\mathrm{E}_{0}=$ the expectation operator at time $\mathrm{t}$.

$\mathrm{U}()=$. the utility function.

$\mathrm{c}_{0}=$ the consumption of the investor at time $\mathrm{t}=0$.

$\mathrm{c}_{1}=$ the consumption of the investor at time $\mathrm{t}=1$.

$\gamma=$ the discount rate.

$Q_{0}=$ the amount of funds lent (borrowed).

$\mathrm{w}_{0}$ and $\mathrm{w}_{1}=$ the endowments at time $\mathrm{t}=0$ and $\mathrm{t}=1$.

$\Theta=$ a parameter indicating a "variable gift"(4)

The Langrangian L can be written as follows:

$$
\mathrm{L}=\mathrm{E}_{0}\left\{\left[\mathrm{U}\left(\mathrm{c}_{0}\right)+\gamma \mathrm{U}\left(\mathrm{c}_{1}\right)\right]+\lambda_{0}\left[\mathrm{w}_{0}-Q_{0}-\mathrm{c}_{0}\right]+\lambda_{1} \gamma\left[\mathrm{w}_{1}+Q_{0} \Theta-\mathrm{c}_{1}\right]\right\}
$$

where $\lambda_{0}$ and $\lambda_{1}$ are the Langrangian multipliers. The first-order necessary conditions are:

$$
\begin{aligned}
& \frac{\delta \mathrm{L}}{\delta \mathrm{c}_{0}}={ }_{-} \mathrm{E}_{0} \mathrm{U}^{\prime}\left(\mathrm{c}_{0}\right)=\lambda_{0}, \\
& \frac{\delta \mathrm{L}}{\delta \mathrm{c}_{1}}={ }_{-} \mathrm{E}_{0} \mathrm{U}^{\prime}\left(\mathrm{c}_{1}\right)=\lambda_{1},
\end{aligned}
$$

Using equations (4) and (5), we get:

$$
\frac{\delta \mathrm{L}}{\delta \mathrm{Q}_{0}}=\mathrm{E}_{0}\left\{-\mathrm{U}^{\prime}\left(\mathrm{c}_{0}\right)+\gamma \mathrm{U}^{\prime}\left(\mathrm{c}_{1}\right) \Theta\right\}=0 \Rightarrow \mathrm{U}^{\prime}\left(\mathrm{c}_{0}\right)=\gamma \mathrm{E}_{0}\left\{\mathrm{U}^{\prime}\left(\mathrm{c}_{1}\right) \Theta\right\}
$$

Moreover, the budget constraints (2) and (3) must generally hold in period $(t=1)^{(5)}$. The second-order conditions for a maximum are verified by showing that the bordered Hessian matrix be a negative semi-definite.

(4) This gift parameter signifies an uncertain amount in addition to the principal paid only if there be excess revenue above the minimum level $\mathrm{T}_{0}$. This extra amount is not guaranteed and is a function of the government tax revenues. Such scheme is consistent with the teaching of Islam as pointed out by A.H. Siddiqi (1986). In particular, Siddiqi points out that Imam Shawkani in his well-known book Nail ul-Autar quoted one Hadeeth in Sahih Muslim that allows the excess payment over the loan amount if it is made out voluntarily.

(5) Observe that a problem would arise if $\partial \mathrm{L} / \partial \lambda=0$ since this would imply that $\mathrm{E}_{0}\left[\mathrm{w}_{1}+\mathrm{Q}_{0} \Theta-\mathrm{c}_{1}\right]=0$. In this case, the constraint (2) would hold only in the expected value sense. Such an issue can be avoided by assuming that the constraint (2) holds in general and in every state of the economy in period $\mathrm{t}=1$. 


\section{B. The Market Clearing Condition}

The following conditions are required for equilibrium:

(i) For the money market to be in equilibrium: $\left(\mathrm{Q}_{0}\right)_{\text {Borrowed }}=\left(\mathrm{Q}_{0}\right)_{\text {Lent }}=\mathrm{Q}_{0}$

(ii) For the government loan to be default free:(6) $\Theta_{\text {Min }}=1$

(iii) For non-usurious loans: funds lent $=\mathrm{Q}_{0}=$ funds guaranteed to be returned $=\mathrm{T}_{\min }=\mathrm{T}_{0}$.

(iv) Tax revenues of the government $\mathrm{T} \geq \mathrm{Q}_{0} \Theta$. This condition is needed to satisfy the government budget constraint.

\section{Model Solutions ${ }^{(7)}$ \\ Case 1: Risk Neutrality}

Since $\mathrm{U}\left(\mathrm{c}_{\mathrm{i}}\right)=\mathrm{c}_{\mathrm{i}}$, then $\mathrm{U}^{\prime}\left(\mathrm{c}_{\mathrm{i}}\right)=1$.

Substituting this in equation (6) we get: $\gamma \mathrm{E}_{0}\{\Theta\}=1 \Rightarrow \mathrm{E}_{0}\{\Theta\}=1 / \gamma$

Since debt is default-free, we have $\mathrm{Q}_{0}=\mathrm{T}_{\min }=\mathrm{T}_{0}$.

The model solution is thus given by:

$\mathrm{c}_{0}=\mathrm{w}_{0}-\mathrm{Q}_{0}=\mathrm{w}_{0}-\mathrm{T}_{0}$, and

$c_{1}=w_{1}+Q_{0} \Theta=w_{1}+T_{0} \Theta$, where $\Theta$ satisfies equation (6)'.

\section{Case 2: Risk Averse}

The analysis that follows assumes that the utility function obey a constant relative risk aversion (CRRA). The reason for selecting the CRRA utility is that if the investor has decreasing absolute risk aversion and constant relative risk aversion, he would then invest more in risky assets as his wealth increases, though the percentage invested in risky assets remains constant. This assumption appears consistent with actual practices of investors, particularly in the pension funds portfolio, where a fixed proportion of about $4 \%$ is typically allocated to real estate. Several researchers like Blume and Friend (1975) and Hodrick (1989) have also recommended the use of CRRA utility functions for their convenience and ease of modeling.

With a CRRA utility function, we have:

$$
\mathrm{U}\left(\mathrm{c}_{\mathrm{i}}\right)=\left(\frac{\left[\mathrm{c}_{\mathrm{i}}\right]^{1-\alpha}}{1-\alpha}\right) \Rightarrow \mathrm{U}^{\prime}\left(\mathrm{c}_{\mathrm{i}}\right)=\left(\frac{1}{\left[\mathrm{c}_{\mathrm{i}}\right] \alpha}\right)
$$

Substituting this in equation (6) we get:

$$
\left(\frac{1}{\left[c_{o}\right] \alpha}\right)=\gamma \mathrm{E}_{\mathrm{o}}\left\{\frac{\Theta}{\left[\mathrm{c}_{1}\right] \alpha}\right\}
$$

Since $c_{o}=w_{0}-Q_{0}=w_{0}-T_{0}$, and $c_{1}=w_{1}+Q_{0} \Theta=w_{1}+T_{0} \Theta$, we can substitute these and solve iteratively for $\Theta$, given the distribution of the tax returns. We obtain:

$$
\left(\frac{1}{\left[\mathrm{w}_{\mathrm{o}}-\mathrm{T}_{\mathrm{o}}\right]^{\alpha}}\right)=\gamma \mathrm{E}_{\mathrm{o}}\left\{\left(\frac{\Theta}{\left[\mathrm{w}_{1}-\mathrm{T}_{\mathrm{o}} \Theta\right]^{\alpha}}\right)\right\}
$$

(6) It should be noted that the default-free aspect of the loan may be questionable from the Shariah standpoint since the possibility of a capital loss is ruled out. Muslim jurists are invited to address this important issue.

(7) We implicitly assume that there are no initial capital constraints. i.e. $\mathrm{w}_{0}>\mathrm{Q}_{0}=\mathrm{T}_{0}$. 
The above equation presents the optimal gift parameter anticipated by the investor which may or may not materialize. Thus, the solution to the model is given by:

$$
\mathrm{c}_{\mathrm{o}}=\mathrm{w}_{\mathrm{o}}-\mathrm{Q}_{\mathrm{o}}=\mathrm{w}_{\mathrm{o}}-\mathrm{T}_{\mathrm{o}}
$$

$c_{1}=w_{1}-Q_{0} \Theta=w_{1}-T_{0} \Theta$, where $\Theta$ satisfies equation (11) above (13)

\section{Efficiency of the Proposed Interest-Free Instrument}

\section{Case A. Risk Neutral Investor}

Lemma 1: For a risk neutral investor, the interest-free instrument is equally efficient to the interest-based instrument.

Proof: In the interest-free security case, the sum of expected utility = total utility. The latter is equal to:

$$
\begin{aligned}
\mathrm{E}_{\mathrm{o}}\left\{\mathrm{U}\left(\mathrm{c}_{\mathrm{o}}\right)+\gamma \mathrm{U}\left(\mathrm{c}_{1}\right)\right\}=\left(\mathrm{c}_{\mathrm{o}}\right)+\gamma \mathrm{E}_{\mathrm{o}}\left(\mathrm{c}_{\mathrm{o}}\right) & =\left(\mathrm{w}_{\mathrm{o}}-\mathrm{Q}_{\mathrm{o}}\right)+\gamma \mathrm{E}_{\mathrm{o}}\left(\mathrm{w}_{1}+\mathrm{Q}_{\mathrm{o}} \Theta\right) \\
& =\left(\mathrm{w}_{\mathrm{o}}+\gamma \mathrm{w}_{1}\right)+\left(-\mathrm{Q}_{0}+\gamma \mathrm{E}_{\mathrm{o}}\left(\mathrm{Q}_{\mathrm{o}} \Theta\right)\right) \\
& =\left(\mathrm{w}_{\mathrm{o}}+\gamma \mathrm{w}_{1}\right), \text { using equation }(6)^{\prime}
\end{aligned}
$$

Similarly, we can prove that in the case of interest-based security, the sum of expected utility $=\left(\mathrm{w}_{0}+\gamma \mathrm{w}_{1}\right)$. Thus, both types of securities are equally efficient in case of risk neutral investor.

\section{Case B. Risk Averse Investor}

In this case, we need to test for efficiency using some numerical simulation. Assume that:

(i) $\mathrm{w}_{0}=2, \gamma=0.9$,

(ii) Tax revenues of the government are assumed to be binomially distributed with equal probabilities of both states such that the minimum tax revenue $\mathrm{T}_{0}=1$, and $\mathrm{T}_{\mathrm{Max}} \geq$ $\mathrm{Q}_{\mathrm{o}} \Theta_{\mathrm{Max}}$, where $\Theta_{\mathrm{Max}}$ or $\Theta_{\mathrm{Good}}$ is endogenously determined.

(iii) $\mathrm{w}_{1}$ is assumed to be $0,0.1,0.25$ respectively in Cases A-C (see the tables).

(iv) The coefficient of risk aversion $(\alpha)$ is assumed to be $0.25,0.5,0.75,1,2,5,10,15$, and 20 , respectively.

Lemma 2: For a risk averse investor, under the above assumptions and the condition explained below, the interest-free security is more efficient than the interest-based security.

Proof: The results from the numerical simulation are presented in Tables 1 and 2. The numerical solution for the interest-free security is possible only for the coefficient of risk aversion $\alpha<1$. The total expected utility of the investor $\left(E_{0}\left\{U\left(c_{o}\right)+\gamma U\left(c_{1}\right)\right\}\right)$, denoted as Sum $\mathrm{U}($ ), is higher in the case of the interest-free security as compared to the interest-based security case ${ }^{(8)}$. Therefore, in case of investors with coefficient of risk aversion less than one, this form of financing is more efficient. The reason

(8) The simulation results show some unique results. In case A, the interest rate is a decreasing function of the coefficient of risk aversion. However, in case B, one finds interest rate as a constant function of the coefficient of risk aversion. These results are contrary to the prevalent belief that interest rates should always be an increasing function of the coefficient of risk aversion. These interesting results are primarily due to the principle of consumption smoothening. 
for this is that the investor gets an extra payment in the good state of the economy from the government. The amount loaned is also higher in the case of the interest-free security, enhancing the availability of funds for development projects $^{(9)}$.

\section{Conclusion}

This paper attempts to design interest-free financing instruments that can be used to finance short-term government projects ${ }^{(10)}$. It has been shown that in the case of risk neutral investors, the proposed interest-free security is at least equally efficient compared to the interest-based security. However, for the more realistic case of risk averse investors, the numerical simulation suggests that, within reasonable limits of the coefficient of risk aversion, the interest-free scheme appears more efficient than the interest-based alternative. This is because in a good state of the economy, the government generates a surplus income which is possibly gifted to the investor. The government can make this form of financing more appealing to the general public by not taxing the extra payment in the good state of the economy. In contrast, most western governments fully tax the interest returns from financial securities $^{(11)}$.

Table $1 *$ (Islamic Economy)

Numerical simulation for interest-free financial instruments, assuming $\mathrm{w}_{0}=2, \gamma=0.9, \mathrm{~T}_{0}=1, \Theta_{\mathrm{Min}}=\Theta_{\mathrm{Bad}}=1$ :

\begin{tabular}{|c|c|c|c|c|c|c|}
\hline \multicolumn{7}{|l|}{ Case A: $\mathrm{w}_{1}=0, \mathrm{Q}_{0}=1$, and $\mathrm{c}_{0}=1$} \\
\hline & & & & & \\
\hline & $\Theta_{\mathrm{Good}}$ & $\mathrm{c}_{1 \mathrm{Bad}}$ & $\mathrm{c}_{1 \mathrm{Good}}$ & $\mathrm{U}\left(\mathrm{C}_{0}\right)$ & $\mathrm{E}_{0}\left[\mathrm{U}\left(\mathrm{C}_{1}\right)\right]$ & $\mathrm{Sum} \mathrm{U}()$ \\
\hline & & & & & & \\
0.1 & 1.2498 & 1 & 1.2498 & 1.111 & 1.2346 & 2.2222 \\
0.2 & 1.2851 & 1 & 1.2851 & 1.250 & 1.3889 & 2.5000 \\
0.3 & 1.3320 & 1 & 1.3320 & 1.429 & 1.5873 & 2.8571 \\
0.4 & 1.3972 & 1 & 1.3972 & 1.667 & 1.8519 & 3.3333 \\
0.5 & 1.4938 & 1 & 1.4938 & 2.000 & 2.2222 & 4.0000 \\
0.6 & 1.6515 & 1 & 1.6515 & 2.500 & 2.7778 & 5.0000 \\
0.7 & 1.9521 & 1 & 1.9521 & 3.333 & 3.7037 & 6.6667 \\
1.00 & N.F. & 1 & N.F. & 0.000 & N.F. & N.F. \\
20.00 & N.F. & 1 & N.F. & -0.053 & N.F. & N.F. \\
\hline
\end{tabular}

(9) Note that the benchmark wealth $w^{*} 0$ for the two schemes (i.e. the interest-free and the Ribawi is defined as that level of wealth which equates the utility of both schemes. An Islamic government is supposed to ensure a basic standard of living through Zakat, Sadaqah or other forms of taxation. The scheme discussed in the text would work only if the government strives for improving the welfare of all residents.

(10) Long-term project financing can be provided by (i) sale of equity security in the project, and/or (ii) Participating Debt. See Kahf (1992).

(11) Ebrahim (1993) calculated the after-tax average real rate of returns of Treasury Bills in the U.S. (1929-89) and in Canada (1950-87) and found them to be as low as $0.5 \%$ and $1.07 \%$ respectively. Indeed, Siegel (1992) even reported negative after-tax average real rate of returns of the U.S. Treasury Bills of about $-0.3 \%$ over the period 1926-1990. 


\begin{tabular}{|c|c|c|c|c|c|c|}
\hline \multicolumn{6}{|l|}{ Case B: $\mathrm{w}_{1}=0.0 .1, \mathrm{Q}_{0}=1$, and $\mathrm{c}_{0}=1$} & \\
\hline & & & & & \\
\hline & $\Theta_{\mathrm{Good}}$ & $\mathrm{c}_{1 \mathrm{Bad}}$ & $\mathrm{c}_{1 \mathrm{Good}}$ & $\mathrm{U}\left(\mathrm{C}_{0}\right)$ & $\mathrm{E}_{0}\left[\mathrm{U}\left(\mathrm{C}_{1}\right)\right]$ & $\mathrm{Sum} \mathrm{U}()$ \\
\hline & & & & & & \\
0.1 & 1.2712 & 1.1 & 1.3712 & 1.1111 & 1.3434 & 2.3202 \\
0.2 & 1.3339 & 1.1 & 1.4339 & 1.2500 & 1.5084 & 2.6075 \\
0.3 & 1.4169 & 1.1 & 1.5169 & 1.4286 & 1.7198 & 2.9763 \\
0.4 & 1.5324 & 1.1 & 1.6324 & 1.6667 & 2.0006 & 3.4672 \\
0.5 & 1.7042 & 1.1 & 1.8042 & 2.0000 & 2.3920 & 4.1428 \\
0.6 & 1.9868 & 1.1 & 2.0868 & 2.5000 & 2.9762 & 5.1786 \\
0.7 & 2.5362 & 1.1 & 2.6362 & 3.3333 & 3.9442 & 6.8831 \\
1.00 & N.F. & 1.1 & N.F. & 0.0000 & N.F. & N.F. \\
20.00 & N.F. & 1.1 & N.F. & -0.0530 & N.F. & N.F. \\
\hline
\end{tabular}

\begin{tabular}{|c|c|c|c|c|c|c|}
\hline \multicolumn{7}{|c|}{ Case C: $\mathrm{w}_{1}=0.25, \mathrm{Q}_{0}=1$, and $\mathrm{c}_{0}=1$} \\
\hline & & & & & & \\
$\alpha$ & $\Theta_{\mathrm{Good}}$ & $\mathrm{c}_{1 \mathrm{Bad}}$ & $\mathrm{c}_{1 \mathrm{Good}}$ & $\mathrm{U}\left(\mathrm{C}_{0}\right)$ & $\mathrm{E}_{0}\left[\mathrm{U}\left(\mathrm{C}_{1}\right)\right]$ & $\mathrm{Sum} \mathrm{U}()$ \\
\hline & & & & & & \\
0.1 & 1.3000 & 1.25 & 1.5500 & 1.1111 & 1.5033 & 2.4641 \\
0.2 & 1.3991 & 1.25 & 1.6491 & 1.2500 & 1.6797 & 2.7617 \\
0.3 & 1.5300 & 1.25 & 1.7800 & 1.486 & 1.9045 & 3.1426 \\
0.4 & 1.7123 & 1.25 & 1.9623 & 1.6667 & 2.2015 & 3.6480 \\
0.5 & 1.9851 & 1.25 & 2.2351 & 2.0000 & 2.6131 & 4.3517 \\
0.6 & 2.4400 & 1.25 & 2.6900 & 2.5000 & 3.2237 & 5.4013 \\
0.7 & 3.3518 & 1.25 & 3.6018 & 3.3333 & 4.2300 & 7.1404 \\
1.00 & N.F. & 1.25 & N.F. & 0.0000 & N.F. & N.F. \\
20.00 & N.F. & 1.25 & N.F. & -0.0530 & N.F. & N.F. \\
\hline
\end{tabular}

* Notes: N. F. means 'Note feasible' and the subscripts Good and Bad denote the two possible states of abinomial distribution. $\alpha$ is the coefficient of risk aversion, $\gamma$ is the discount factor, $\Theta$ is the variable gift from the government, $T_{0}$ is the minimum tax revenue, $\mathrm{Q}_{\mathrm{o}}$ is the loan amount, $\mathrm{C}_{\mathrm{o}}$ and $\mathrm{C}_{1}$ are the consumption levels in period 1 and 2 respectively, $\mathrm{w}_{\mathrm{o}}$ and $\mathrm{w}_{1}$ are the endowment levels in periods 1 and 2 respectively, and $\mathrm{U}($ ) represent the utility of the investor.

Table 2* (Non-Islamic Economy)

Numerical simulation for interest-based financial instruments, assuming $\mathrm{w}_{0}=2, \gamma=0.9, \mathrm{~T}_{0}=1$,

\begin{tabular}{|c|c|c|c|c|c|c|}
\hline \multicolumn{7}{|c|}{ Case A: $\mathrm{w}_{1}=0$} \\
\hline
\end{tabular}




\begin{tabular}{|c|c|c|c|c|c|c|}
\hline \multicolumn{7}{|l|}{ Case B: $\mathrm{w}_{1}=0.1$} \\
\hline
\end{tabular}

\begin{tabular}{|c|c|c|c|c|c|c|}
\hline \multicolumn{7}{|l|}{ Case C: $\mathrm{w}_{1}=0.25$} \\
\hline & & & & & \\
\\
$\alpha$ & $\mathrm{c}_{0}$ & $\mathrm{Q}_{0}$ & $\mathrm{i}$ & $\mathrm{U}\left(\mathrm{C}_{0}\right)$ & $\mathrm{U}\left(\mathrm{C}_{1}\right)$ & $\mathrm{Sum} \mathrm{U}()$ \\
\hline & & & & & & \\
0.1 & 1.1106 & 0.8894 & $12.43 \%$ & 1.2211 & 1.3582 & 2.4435 \\
0.2 & 1.1196 & 0.8804 & $13.59 \%$ & 1.3682 & 1.4943 & 2.7131 \\
0.3 & 1.1274 & 0.8726 & $14.60 \%$ & 1.5537 & 1.6701 & 3.0568 \\
0.4 & 1.1343 & 0.8652 & $15.51 \%$ & 1.7976 & 1.9054 & 3.5125 \\
0.5 & 1.1404 & 0.8596 & $16.33 \%$ & 2.1358 & 2.2361 & 4.1482 \\
0.6 & 1.1458 & 0.8542 & $17.07 \%$ & 2.6399 & 2.7334 & 5.0999 \\
0.7 & 1.1507 & 0.8493 & $17.74 \%$ & 3.4767 & 3.5641 & 6.6844 \\
1.00 & 1.1628 & 0.8372 & $19.44 \%$ & 0.0655 & 0.0969 & 0.1527 \\
20.00 & 1.2395 & 0.7605 & $31.50 \%$ & -0.0009 & -0.0008 & -0.0016 \\
\hline
\end{tabular}

See notes to Table 1 . The symbol i represents the faced rate of interest. Details of the calculations are available from the authors upon request.

\section{References}

Bashir, A. M., and Darrat, A. F. (1992), "Equity Participation Contracts and Investment," American Journal of lslamic Social Sciences (9) Summer: 219-232.

, and Suliman, M. O. (1993), "Equity Capital, Profit-Sharing Contracts and Investment: Theory and Evidence," Journal of Business Finance and Accounting (forthcoming).

Blume, M., and Friend, I. (1975), "The Asset Structure of Individual Portfolios and Some Implications for Utility Functions," Journal of Finance (10): 585-603.

Dorph, K. (1990), "International Islamic Banking," in: Bassiouni, M. C., Badr, G. M., and Dorph, K., eds. Interest and Banking in Islamic Law, Chicago: Mid-America Arab Chamber of Commerce.

Ebrahim, M. S. (1992), "Views and Comments on: Commodity Exchange and Stock Exchange in an Islamic Economy," American Journal of lslamic Social Sciences (9): 284-287.

(1993), "Investing in Equities Versus Debt: The Islamic Perspective. Working Paper, Department of Business and Economics, Rosary College.

Hodrick, R. J. (1989), "U.S. International Capital Flows: Perspectives from Rational Maximizing Models," National Bureau of Economic Research, Reprint No. 1307.

Kahf, M. (1992), "Financing the Public Sector in an Islamic Perspective," in: Sattar Z., (ed.), Resource Mobilization and Investment in an Islamic Economic Framework, Herndon, VA: The Association of Muslim Social Scientists and The International Institute of Islamic Thought. 
Khan, M. F. (1983), "Islamic Banking as Practiced Now in the world, " in: Khan, M. F., Ahmad, Z., and Iqbal, M., (eds.), Money and Banking in Islam, Jeddah, Saudi Arabia: International Center for Research in Islamic Economics.

Kindleberger, C. P. (1985), "Bank Failures: The 1930s and the 1980s," paper presented at: The Conference on The Search for Financial Stability: The Past 50 Years, San Francisco.

Mirakhor, A. (1988), "The Progress of Islamic Banking: The Case of Iran and Pakistan," in: Mallat, C. (ed.), Islamic Law and Finance, Boston: Graham \& Trotman, pp. 47-70.

Siddiqi, A. H.(1986), Translation of Sahih Muslim, New Delhi: Kitab Bhaven.

Siddiqi, M. N. (1991), "Some Economic Aspects of Mudarabah," Review of Islamic Economics (1): 21-33.

Siegel, J. J. (1992), "The Equity Premium: Stock and Bond Returns Since 1802," Financial Analyst Journal, January/February: 28-46.

Simon, H. C. (1948), Economic Policy for a Free Society, Chicago: The University of Chicago Press.

Zaman, R. (1992), "The Operation of the Modern Financial Markets for Stocks and Bonds and its Relevance to Our Islamic Economy," in: Ghazali, S. A., Syed, O. S. A., and Aidit, G., (eds.), An Introduction to Islamic Finance, Boston: Quill Publishers. 


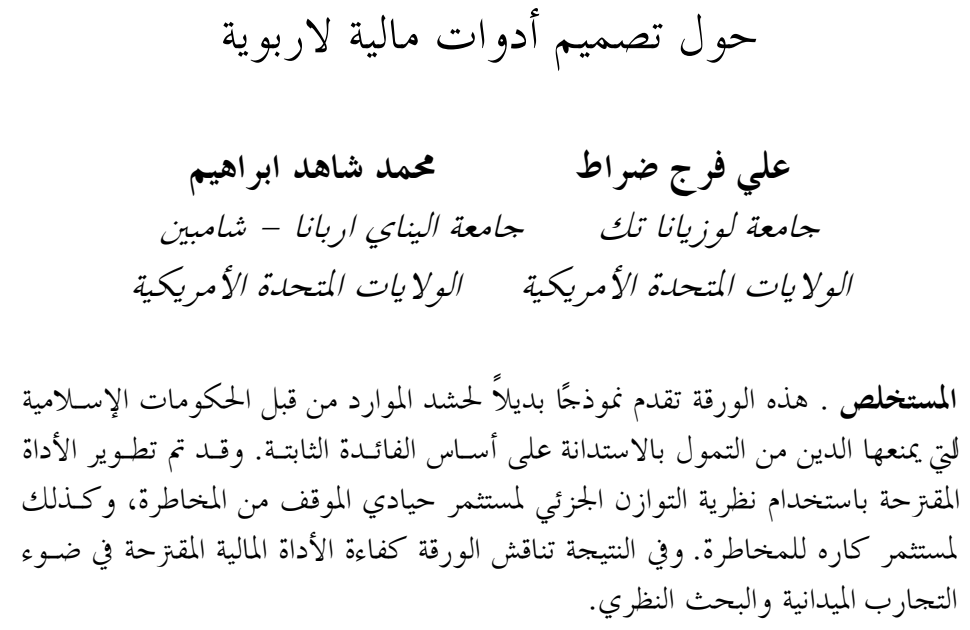

